\title{
ANALISIS PERKEMBANGAN INDUSTRI KECIL DAN RUMAH TANGGA DENGAN PENDEKATAN DPSIR: STUDI KASUS DI KECAMATAN CIPARAY, KABUPATEN BANDUNG
}

\author{
Analysis of Small and Household Industry Development with DPSIR \\ Method, Case study in Ciparay District, Bandung Regency
}

\section{Nurrohman Wijaya ${ }^{1}$ dan Muhammad Aziz Ali Mutia}

Diterima: Februari 2016 Disetujui: Juli 2016

\begin{abstract}
Abstrak. Usaha Mikro, Kecil dan Menengah (UMKM) memiliki potensi yang strategis dalam kontribusinya terhadap pertumbuhan ekonomi lokal di Indonesia. Seiring dengan peningkatan sektor ekonomi dan dinamika penduduk di Kecamatan Ciparay, UMKM yang bergerak pada industri pengolahan mulai berkembang khususnya usaha industri kecil dan rumah tangga (IKRT). Namun, keberadaan industri tersebut belum berjalan secara optimal. Artikel ini bertujuan untuk menganalisis perkembangan usaha IKRT yang terdapat di Kecamatan Ciparay melalui pendekatan DPSIR (Driver, Pressure, State, Impact and Response). Studi ini menggunakan metode penelitian deskriptif. Penyebaran kuesioner, wawancara dan observasi lapangan telah dilakukan di wilayah studi. Temuan studi memperlihatkan bahwa perkembangan IKRT dipicu beberapa faktor pendorong diantaranya yaitu industrialisasi, dinamika sosial dan ekonomi, serta strategi dan kebijakan daerah. Pendekatan model DPSIR telah mampu mengidentifikasi beberapa faktor pendorong dan dampak perkembangan IKRT terhadap suatu sistem secara menyeluruh. Perhatian yang cukup dari pemerintah daerah dan pembuat kebijakan menjadi sorotan penting dalam mendukung UMKM di Kecamatan Ciparay.
\end{abstract}

Kata kunci. DPSIR, ekonomi lokal, industri kecil dan rumah tangga, Kecamatan Ciparay

\begin{abstract}
Micro, Small, and Medium-Sized Enteprises (UMKM) have a significant potential in contribution to local economic development in Indonesia. Within the development of economic sector and a dynamic population in Kecamatan Ciparay, UMKM of manufacturing industry is increasing as well, especially the small and home industries. Nevertheless, the industries still not put into practice optimally yet and give less contribution to the local economy. This article aims to analyze the development of the small and home industries in Kecamatan Ciparay with an analysis approach of DPSIR (Driver, Pressure, State, Impact and Response). The study applied descriptive research method. Questionnaire, interview and field observation were conducted in the study area. The results found that the development of the small and home industries is driven by some driver factors such as industrialization, socio-economic dynamic as well as local policy and strategy aspects. DPSIR model approach has identified some driver factors and the impacts of the small and home industries in a comprehensive system. A considerable attention of local government and decision makers becomes crutial focal point in order to support the UMKM in Kecamatan Ciparay.
\end{abstract}

Keywords. DPSIR, local economy, small and home industry, Kecamatan Ciparay

\footnotetext{
${ }^{1}$ Program Studi Perencanaan Wilayah dan Kota, Institut Teknologi Bandung
}

Korespondensi: nurrohman.wijaya@sappk.itb.ac.id; muh.azizalimutia@gmail.com 


\section{PENDAHULUAN}

Keberadaan Usaha Mikro, Kecil dan Menengah (UMKM) di Indonesia memiliki potensi yang strategis dalam mempercepat pertumbuhan ekonomi lokal, khususnya dalam hal penyerapan tenaga kerja dan kontribusi terhadap pendapatan nasional. Menurut data dari Kementerian Koperasi dan UMKM (2013), jumlah UMKM di Indonesia pada tahun 2012 tercatat sebanyak 56,53 juta unit dan mampu menyerap tenaga kerja sebesar 97,16 persen (107,65 juta orang) dengan kontribusi terhadap produk domestik bruto nasional sebesar 59,08 persen (4.869 triliun rupiah). Perkembangan UMKM setiap tahun terus meningkat dengan tingkat pertumbuhan sebesar 2,3 persen per tahun dalam kurun waktu 2007 hingga 2012. Salah satu sektor UMKM yang memiliki peran signifikan dalam perekonomian Indonesia adalah industri kecil dan rumah tangga (IKRT) atau usaha mikro dan kecil (UMK). Dari total unit usaha yang ada, sebanyak 99,9 persen merupakan UMK dengan usaha mikro sebesar 98,79 persen dan usaha kecil sebesar 1,11 persen. Hal ini mengindikasikan bahwa usaha IKRT memiliki peranan yang cukup strategis dalam perkembangan ekonomi di Indonesia, khususnya dalam peningkatan ekonomi lokal di wilayah perdesaan.

Definisi IKRT atau UMK di Indonesia pada umumnya mengacu dari dokumen Badan Pusat Statistik (BPS) dimana yang menjadi ukuran dalam pengkategorian adalah jumlah tenaga kerja yang dimiliki. Industri rumah tangga memiliki tenaga kerja berjumlah kurang dari 5 orang, sedangkan industri kecil berjumlah 5 hingga 19 orang tenaga kerja. Sementara itu, menurut Undang-Undang Republik Indonesia Nomor 20 Tahun 2008 tentang UMKM, pengelompokkan berdasarkan nilai aset atau kekayaan yang dimiliki, dan hasil penjualan per tahun. Usaha mikro memiliki kekayaan bersih maksimal 50 juta rupiah termasuk tanah dan bangunan tempat usaha, serta memiliki hasil penjualan tahunan maksimal 300 juta rupiah. Sedangkan, usaha kecil memiliki kekayaan bersih lebih dari 50 juta sampai dengan 500 juta rupiah tidak termasuk tanah dan bangunan tempat usaha, serta memiliki hasil penjualan lebih dari 300 juta hingga 2,5 miliar rupiah.

Perkembangan ekonomi dan dinamika penduduk di wilayah perdesaaan di Indonesia telah mengakibatkan berkembangnya usaha IKRT. Sementara itu, akibat kondisi perekonomian dan tingkat pendapatan masyarakat yang masih rendah, IKRT pada umumnya bergerak pada usaha industri pengolahan yaitu usaha yang memproduksi barang-barang yang sederhana dan terjangkau yang berasal dari bahan mentah menjadi barang jadi atau setengah jadi, diantaranya produk kerajinan dan pangan. Fenomena ini sesuai dengan teori pentahapan (stage theory) yang dikemukakan oleh Dennis Anderson (1982). Beliau menjelaskan bahwa suatu daerah yang memiliki tingkat ekonomi dan pendapatan masyarakat yang rendah, jumlah industri rumah tangga yang menghasilkan produk sederhana dan murah sangat dominan di sektor manufaktur, sedangkan di daerah yang sudah maju pembangunannya, industri kecil dan terutama industri skala menengah dan besar didominasi oleh barang yang mutakhir. Rahmayanti (2007) menguraikan beberapa karakteristik IKRT sebagai berikut: (1) merupakan usaha padat karya yang diharapkan dapat menyerap angkatan kerja di wilayah perdesaan, (2) modal awal usaha yang relatif kecil, (3) menggunakan teknologi yang relatif sederhana, (4) sebaran industri berada di daerah pedesaan dengan menggunakan sumber daya dan bahan baku lokal.

Kecamatan Ciparay merupakan salah satu kecamatan yang terdapat di Kabupaten Bandung, Provinsi Jawa Barat yang terkenal sebagai sumber penghasil produk pertanian untuk distribusi wilayah Kabupaten Bandung dan sekitarnya. Luas lahan pertaniannya mencapai 63 persen dari luas total wilayah kecamatan (Kecamatan Ciparay dalam Angka, 2014). Namun, semakin berkembangnya perekonomian dan meningkatnya jumlah 
penduduk, sektor industri pengolahan khususnya IKRT terus bermunculan. Keberadaan industri pengolahan di Kecamatan Ciparay telah menyerap tenaga kerja sebesar 34,5 persen dari total masyarakat yang bekerja di sektor industri. Keberadaan beberapa industri besar di Kecamatan Majalaya juga telah mempengaruhi keberadaan IKRT di Kecamatan Ciparay. Wilayah Kecamatan Ciparay di bagian timur berbatasan langsung dengan Kecamatan Majalaya dan merupakan jalur distribusi produksi industri dari Kecamatan Majalaya yang memberikan pengaruh bagi perkembangan industri di Kecamatan Ciparay. Meskipun Kecamatan Ciparay memiliki jumlah IKRT yang besar, namun pendapatan produk domestik regional bruto (PDRB) industri pengolahan di Kecamatan Ciparay masih termasuk pada urutan yang rendah di Kabupaten Bandung (Kabupaten Bandung Dalam Angka, 2014). PDRB per kapita Kecamatan Ciparay masuk dalam kategori rendah yaitu berada dibawah 8 juta rupiah per tahun. Selain itu, jumlah keluarga miskin di Kecamatan Ciparay berada pada posisi kedua yang terbanyak dalam peringkat seluruh kecamatan di Kabupaten Bandung.

Keberadaan IKRT diharapkan dapat menjadi penggerak pertumbuhan ekonomi lokal di wilayah perdesaan, selain sektor pertanian terutama dalam rangka peningkatan kemampuan ekonomi masyarakat pedesaan. Namun, pada kenyataannya hal itu tidak berjalan secara optimal. Oleh karena itu, studi ini bertujuan untuk melakukan analisis menyeluruh terhadap perkembangan keberadaan usaha IKRT terkait kurang optimalnya industri tersebut dalam meningkatkan perekonomian lokal di Kecamatan Ciparay. Analisis DPSIR (Driver, Pressure, State, Impact and Response) akan digunakan untuk melihat faktor penyebab dan akibat dari permasalahan yang ada. Selain itu, model pendekatan ini berguna untuk menganalisis keterkaitan antar komponen. Selanjutnya, hasil analisis tersebut dapat digunakan sebagai rekomendasi dan dasar dalam penentuan arah dan strategi kebijakan terhadap masalah yang ada di wilayah studi.

\section{METODE}

Metode yang digunakan dalam studi ini adalah metode pendekatan kualitatif dengan melakukan penelitian secara deskriptif dari hasil survei primer dan pengolahan data sekunder. Survei primer berupa observasi lapangan, wawancara dan penyebaran kuesioner dilakukan terhadap para pelaku usaha kecil dan rumah tangga, masyarakat serta aparat pemerintah yang terkait. Survei lapangan dilakukan di wilayah studi pada bulan Maret 2014. Data sekunder dari institusi terkait digunakan untuk memperkaya hasil analisis studi ini. Dalam rangka untuk mengetahui permasalahan dan keterkaitan sebab-akibat dari perkembangan IKRT di Kecamatan Ciparay, maka digunakan pendekatan DPSIR yang terdiri dari kekuatan pendorong (driving force), tekanan (pressure), kondisi yang terjadi (state), dampak (impact) dan tanggapan (response) (lihat Gambar 1; Smeets dan Waterings, 1999).

\section{Analisis DPSIR}

Kerangka analisis pendekatan DPSIR mulai diterapkan di Eropa pada tahun 1993 oleh Organisasi untuk Kerjasama dan Pembangunan Ekonomi (Organization for Economic Co-operation and Development) dan digunakan secara ekstensif oleh Badan Lingkungan Eropa (European Environmental Agency) pada tahun 1995 dan Badan Lingkungan Inggris (U.K. Environmental Agency). Model ini digunakan untuk menemukali hubungan sebabakibat antara sistem lingkungan dan sistem manusia. Selain itu, bertujuan untuk membantu para pembuat kebijakan memahami atas informasi yang terkait (Smeets dan Waterings, 1999). Model Driver - Pressure - State - Impact - Response (DPSIR) merupakan pengembangan dari model analisis Driving Force - State - Response (DSR) dan Pressure - 
State - Response (PSR). Model ini memberikan pemahaman akan suatu sistem secara menyeluruh dan membantu dalam fasilitasi proses intervensi dan penyusunan kebijakan.

Analisis DPSIR terdiri dari 5 bagian yaitu: (1) Driving forces (faktor pemicu) menjelaskan tentang isu-isu yang sedang terjadi di masyarakat diantaranya kondisi sosial, demografi dan ekonomi serta perubahan dalam gaya hidup, pola produksi dan konsumsi masyarakat, (2) Pressure (tekanan) merupakan jawaban terhadap pertanyaan mengapa terjadi permasalahan tersebut, (3) State (kondisi eksisting) menjelaskan mengenai apa yang terjadi dan keadaan lingkungan pada saat ini, (4) Impact (dampak) merupakan dampak yang timbul dengan adanya isu dan penanggulangan isu, (5) Response (tanggapan) adalah apa saja yang harus dilakukan untuk mengatasi permasalahan-permasalahan yang terjadi dengan melibatkan para pelaku kepentingan.

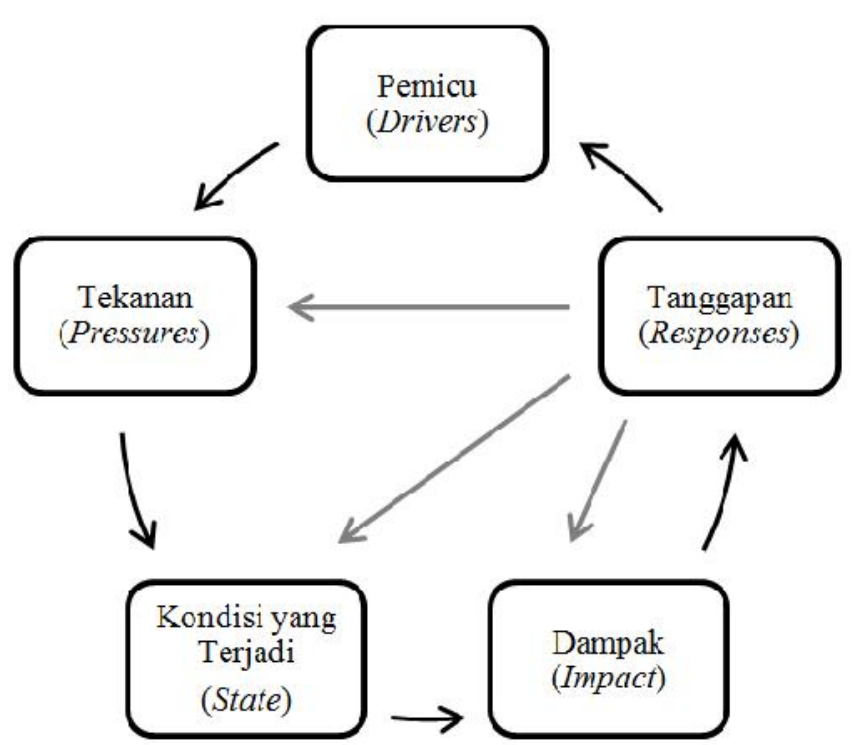

Gambar 1. Pendekatan DPSIR

\section{PEMBAHASAN}

Kecamatan Ciparay merupakan salah satu kecamatan yang terdapat di Kabupaten Bandung, Provinsi Jawa Barat dengan luas wilayah sebesar 4.848,9 hektar (Kecamatan Ciparay Dalam Angka, 2014). Kecamatan ini memiliki tipologi lahan yang datar. Berdasarkan topografinya, sebagian besar wilayah di Kecamatan Ciparay merupakan daerah dataran dengan ketinggian bervariasi dari 623 sampai 750 meter di atas permukaan laut. Sebagian besar wilayahnya didominasi oleh kawasan pertanian berupa persawahan. Secara administratif, kecamatan ini terdiri dari 14 desa. Adapun dilihat dari posisi geografisnya, batas-batas wilayah administratif Kecamatan Ciparay dapat dijabarkan sebagai berikut: pada bagian utara berbatasan dengan Kecamatan Bojongsoang, bagian timur berbatasan dengan Kecamatan Majalaya dan Kecamatan Solokan Jeruk, bagian selatan berbatasan dengan Kecamatan Arjasari dan Kecamatan Pacet, serta bagian barat berbatasan dengan Kecamatan Baleendah (lihat Gambar 2).

Pada tahun 2013, Kecamatan Ciparay memiliki jumlah penduduk sebanyak 161.377 jiwa dengan jumlah penduduk perempuan sebesar 79.040 jiwa dan penduduk laki-laki sebesar 82.337 jiwa. Tingkat kepadatan penduduknya sebesar 3.328 jiwa per kilometer 
persegi. Jumlah penduduk Ciparay yang tergolong pada usia produktif diantara umur 15 hingga 64 tahun berjumlah sebanyak 105.250 jiwa atau sekitar 65 persen dari total penduduk. Sebagian besar tingkat pendidikan penduduk hanya lulusan Sekolah Dasar (SD) dan Sekolah Menengah Pertama (SMP) dengan sebagian besar penduduknya bermata pencaharian di sektor industri pengolahan, pertanian dan bangunan. Indeks Pembangunan Manusia (IPM) Kecamatan Ciparay pada tahun 2013 adalah sebesar 75,55 dimana berada sedikit di atas nilai IPM Kabupaten Bandung yang sebesar 75,40 (Kecamatan Ciparay Dalam Angka, 2014). Secara keseluruhan, nilai IPM Kecamatan Ciparay termasuk pada kategori menengah.

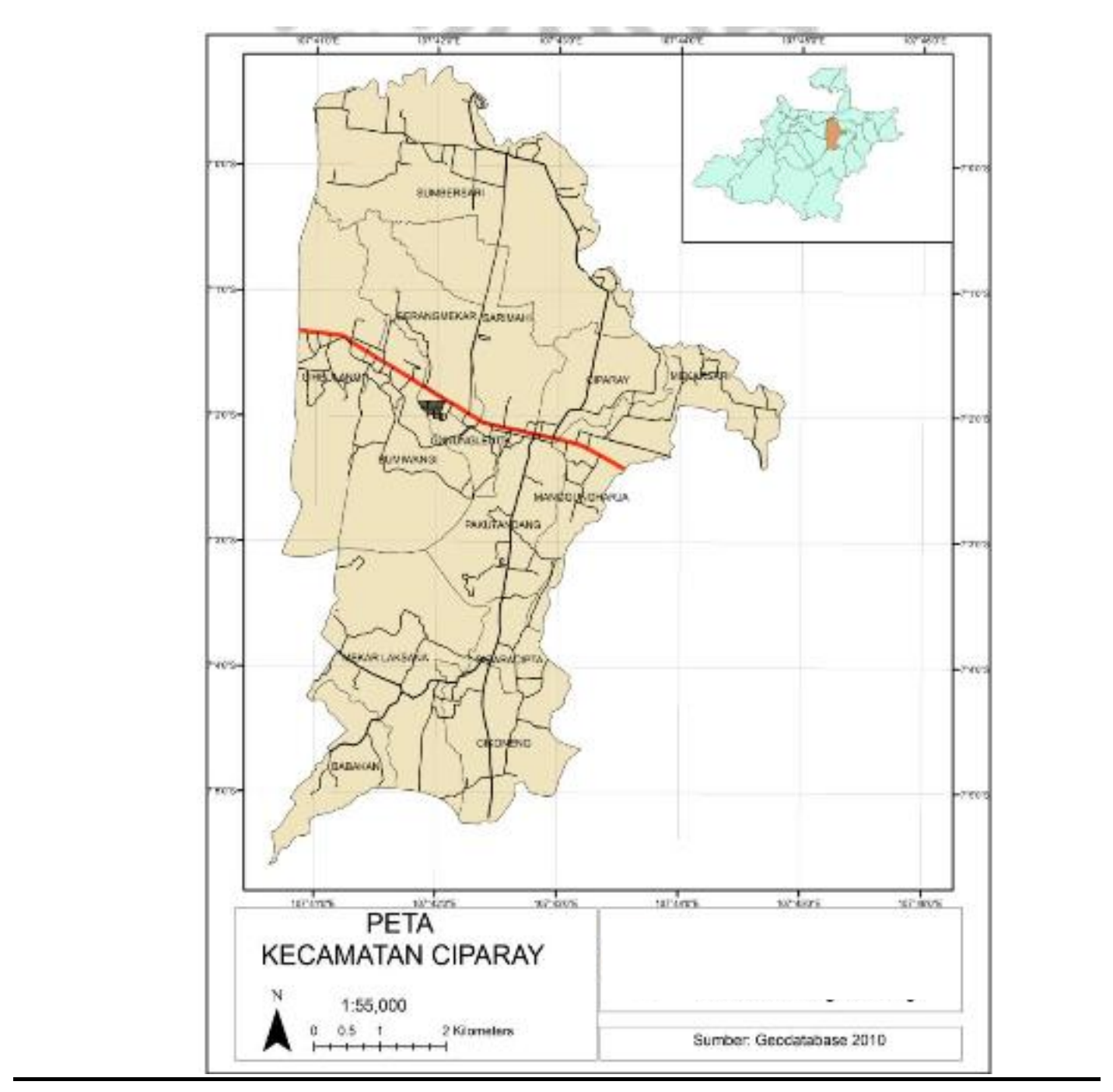

Gambar 2. Peta Wilayah Administrasi Kecamatan Ciparay

Sektor yang terbesar menyumbang PDRB di Kecamatan Ciparay yaitu sektor industri pengolahan, sektor perdagangan, dan sektor pertanian. Sektor industri pengolahan menjadi salah satu mesin pertumbuhan ekonomi di Kecamatan Ciparay. Hal ini telihat dari dominasi sektor ini terhadap kontribusi perekonomian daerah setiap tahunnya. Secara umum, nilai PDRB Kecamatan Ciparay dari tahun ke tahun menunjukan peningkatan 
positif. Salah satu bentuk usaha pada sektor industri pengolahan adalah usaha IKRT yang tersebar di desa-desa yang terdapat di Kecamatan Ciparay. Jumlah IKRT yang terdapat di Kecamatan Ciparay sebanyak 645 industri (Kecamatan Ciparay Dalam Angka, 2014). Hasil produksinya terdiri dari anyaman, gerabah/keramik, makanan dan minuman, kain/tenun, logam mulia dan lainnya. Industri makanan dan minuman, industri gerabah/keramik, dan industri kain/tenun merupakan IKRT yang mendominasi di kecamatan ini yaitu sebanyak 241 industri, 181 industri, dan 143 industri secara berurutan. Masing-masing desa di Kecamatan Ciparay memiliki ciri khas tersendiri dari segi produk yang dihasilkan. Beberapa contohnya adalah industri kecil anyaman yang banyak terdapat di Desa Babakan dan Desa Paku Tandang. Sedangkan, di Desa Ciheulang tersebar industri logam/logam mulia. Pada usaha industri kain tenun, Desa Mekarlaksana dan Desa Babakan menjadi produsen terbanyak dalam menghasilkan produk tekstil tersebut.

Potensi dan peran strategis IKRT yang terdapat di Kecamatan Ciparay diharapkan dapat memberikan kontribusi siginifikan terhadap pertumbuhan ekonomi lokal dan peningkatan kesejahteraan masyarakat pedesaan, namun pada kenyataannya perkembangan usaha IKRT tersebut tidak mampu berjalan secara optimal dalam mencapai tujuan yang akan dicapai. Dalam rangka untuk menguraikan permasalahan yang ada terkait dengan perkembangan usaha IKRT di Kecamatan Ciparay, studi ini menggunakan kriteria DPSIR dalam pembahasannya yang terdiri dari kekuatan pendorong (driver), tekanan (pressure), kondisi yang ada (state), dampak (impact), dan tanggapan (response).

\section{Kekuatan Pendorong}

Terdapat beberapa kekuatan pendorong yang mempengaruhi perkembangan IKRT di Kecamatan Ciparay. Pertama, industrialisasi yang berada di sekitar wilayah studi, khususnya keberadaan kawasan industri yang terdapat di Kecamatan Majalaya. Kawasan Industri Majalaya yang berbatasan langsung dengan Kecamatan Ciparay memberikan peluang bagi Kecamatan Ciparay dalam pengembangan ekonominya khususnya dalam hal permintaan barang dan jasa. Permintaan jasa diantaranya yaitu dalam hal penyediaan tenaga kerja. Sedangkan, dalam kaitannya dengan usaha IKRT, permintaan terhadap barang terutama dari para tenaga kerja yang bekerja di kawasan industri Majalaya telah mendorong tumbuhnya IKRT pengolahan makanan dan minuman. Secara tidak langsung, hal tersebut telah mempengaruhi perkembangan IKRT di Kecamatan Ciparay. Para pelaku ekonomi memberikan tanggapan positif terhadap adanya eksternalitas industrialisasi di Kecamatan Ciparay. Berdasarkan pandangan mereka, hal tersebut mengindikasikan bahwa kondisi perekonomian di Kecamatan Ciparay semakin maju karena tidak hanya bergantung pada sektor pertanian tetapi juga pada sektor industri. Namun, sebagian penduduk memiliki pandangan yang berbeda. Mereka menyayangkan semakin berkurangnya sektor pertanian di Kecamatan Ciparay padahal wilayahnya merupakan lumbung padi di Kabupaten Bandung. Kedua, adanya perubahan dinamika sosial dan ekonomi penduduk. Kecamatan Ciparay dikenal sebagai salah satu wilayah lumbung padi di Kabupaten Bandung. Namun, seiring perkembangan sosial dan ekonomi masyarakatnya, banyak penduduk yang beralih profesi pada sektor non-pertanian, diantaranya usaha IKRT. Mayoritas yang bekerja di sektor pertanian memiliki kondisi ekonomi yang kurang stabil dan miskin. Pertumbuhan ekonomi yang kurang di Kecamatan Ciparay dapat dilihat dari angka PDRB di Kecamatan Ciparay yang rendah apabila dibandingkan dengan kecamatan lain di Kabupaten Bandung. Bahkan, PDRB per kapita Kecamatan Ciparay menempati peringkat ke-28 dari 30 kecamatan yang terdapat di Kabupaten Bandung. Tingkat pekerjaan di sektor pertanian pun mulai terbatas. Menurut keterangan dari salah satu sumber yang bekerja di Kantor Kecamatan Ciparay menyatakan bahwa penduduk usia muda lebih tertarik untuk bekerja pada sektor industri yang terdapat di Kecamatan 
Majalaya dibandingkan yang bekerja pada sektor pertanian di Kecamatan Ciparay. Sementara itu, beberapa penduduk lain juga lebih memilih bekerja di industri kecil dan menengah dibandingkan di sektor pertanian. Salah satu alasan penduduk Kecamatan Ciparay berpindah mata pencaharian yaitu disebabkan sektor industri lebih menjanjikan dibandingkan sektor pertanian. Ketiga, strategi dan kebijakan pembangunan daerah. Menurut Rahmayanti (2007), kebijakan pemerintah merupakan salah satu faktor eksternal yang dapat mempengaruhi perkembangan IKRT. Kebijakan pembangunan daerah di Kecamatan Ciparay kurang mendukung terhadap sektor non-pertanian baik dalam hal pendanaan maupun pembangunan infrastruktur. Selain itu, kurang baiknya pengelolaan dan implementasi kebijakan yang ada mempengaruhi perkembangan IKRT di Kecamatan Ciparay. Keempat, kondisi kualitas sumber daya manusia. Kemampuan masyarakat Kecamatan Ciparay dalam segi pendanaan, pengelolaan dan pemasaran produk usaha IKRT masih cukup rendah. Hal ini terlihat juga dari rendahnya tingkat IPM Kecamatan Ciparay.

\section{Tekanan}

Adapun tekanan yang dihadapi oleh Kecamatan Ciparay terhadap perkembangan ekonomi lokalnya khususnya usaha IKRT dapat diuraikan sebagai berikut. Pertama, perubahan komposisi struktur ekonomi. Keberadaan usaha IKRT mengubah struktur ekonomi Kecamatan Ciparay. Terjadi peningkatan usaha non-pertanian khususnya industri pengolahan dibandingkan usaha sektor pertanian. Selain itu, jumlah tenaga kerja yang bergerak di luar sektor pertanian mulai bertambah. Kedua, meningkatnya penggunaan sumber daya alam. Keberadaan IKRT telah meningkatkan penggunaan air dan energi sebagai pendukung proses produksi. Usaha IKRT juga berdampak terhadap menurunnya luas lahan pertanian di Kecamatan Ciparay. Menurut keterangan dari Kepala Desa Manggungharja bahwa lahan pertanian di Desa Manggungharja semakin berkurang. Desa Manggungharja merupakan salah satu desa yang terdapat di Kecamatan Ciparay. Salah satu penyebabnya yaitu semakin banyak lahan pertanian yang beralih fungsi menjadi lahan yang diperuntukkan untuk kegiatan industri dan permukiman. Selain itu, kurangnya kapasitas pemerintah daerah dalam pengelolaan, pengawasan dan pengendalian terhadap penggunaan sumber daya alam telah mengakibatkan terjadinya penurunan sumber daya alam di Kecamatan Ciparay diantaranya munculnya polusi dan limbah.

\section{Keadaan Yang Terjadi}

Ada beberapa hal terkait kondisi perkembangan IKRT yang terjadi saat ini di Kecamatan Ciparay. Pertama, kondisi sosial dan ekonomi masyarakat yang rendah. Penduduk yang menetap di Kecamatan Ciparay termasuk dalam kategori miskin, dimana jumlah kepala keluarga miskin berada pada urutan terbanyak kedua di Kabupaten Bandung. Hal ini berdampak terhadap daya beli dan tingkat pendidikan masyarakat. Selain itu, berimplikasi terhadap perkembangan dan peningkatan sektor IKRT. Berdasarkan hasil survei (2014) terhadap para pelaku usaha IKRT di Kecamatan Ciparay diperoleh temuan bahwa tingkat pendidikan tenaga kerja yang bekerja di IKRT tergolong rendah. Kedua, kurangnya inovasi dan teknologi pendukung. Berdasarkan hasil survei (2014), variasi produksi IKRT terlihat monoton dan kurangnya teknologi pendukung dalam proses produksi. Hal ini terjadi karena sebagian besar usaha IKRT merupakan usaha turun temurun dari generasi sebelumnya. Menurut Tambunan (1999), tenaga kerja IKRT berasal dari anggota keluarga sendiri atau kerabat dekat yang berada di daerahnya dan biasanya waktu kerja tidak terikat oleh jam kerja dan tempat kerja. Pemilik atau pengelola industri biasanya merupakan kepala keluarga atau anggota keluarga sendiri. Ketiga, kondisi infrastruktur dan prasarana yang kurang memadai. Bedasarkan hasil observasi di wilayah 
studi (2014), terindentifikasi beberapa ruas jalan di Kecamatan Ciparay mengalami kerusakan dan terdapat yang masih belum mengalami perkerasan. Infrastruktur jalan menjadi hal penting dalam aksesibilitas pengangkutan dan distribusi produksi usaha IKRT di Kecamatan Ciparay. Sementara itu, kondisi pasar yang dapat digunakan sebagai media pemasaran produk-produk IKRT dalam kondisi yang kurang memadai. Kondisi sarana dan prasarana yang kurang mendukung dapat menghambat perkembangan IKRT yang terdapat di Kecamatan Ciparay. Keempat, program pemerintah yang kurang terdistribusi merata. Berdasarkan hasil wawancara dengan beberapa kepala desa dan pemilik usaha IKRT di beberapa desa di Kecamatan Ciparay, sebagian besar mengungkapkan bahwa programprogram yang dicanangkan oleh pemerintah, baik tingkat pusat dan daerah, kurang tersebar merata ke seluruh desa, sehingga terjadi kesenjangan antar desa yang terdapat di Kecamatan Ciparay. Selain itu, masih terdapat beberapa kebijakan dan program pemerintah yang belum direalisasikan khususnya dalam menunjang pembangunan perekonomian desa di Kecamatan Ciparay. Kelima, beralihnya mata pencaharian penduduk ke sektor industri. Sebagian besar masyarakat yang tinggal di Kecamatan Ciparay memiliki pekerjaan pada sektor pertanian. Namun, kondisi yang terjadi saat ini terdapat beberapa masyarakat yang mulai beralih mata pencaharian ke sektor industri. Berdasarkan hasil wawancara dengan salah satu pihak yang bekerja di kantor Kecamatan Ciparay dapat diketahui bahwa semakin banyaknya penduduk yang bekerja di sektor industri terlihat dari semakin banyaknya jumlah industri di Kecamatan Ciparay. Keenam, kurangnya inisiatif dari pemerintah daerah dalam upaya pengembangan sektor IKRT. Akibat dari tekanan dan faktor pendorong perkembangan usaha IKRT di Kecamatan Ciparay, pemerintah daerah mengalami kesulitan dalam menciptakan inistiatif terhadap peningkatan ekonomi lokal khususnya pengembangan usaha IKRT di daerahnya. Pemerintah daerah memiliki kecenderungan menunggu dan berharap adanya dukungan dari pemerintah pusat dan provinsi. Potensi kerjasama dengan pihak swasta memiliki peluang yang besar bagi usaha IKRT yang memiliki produk unggul dan berkualitas.

\section{Dampak}

Berbagai dampak akibat perkembangan IKRT di Kecamatan Ciparay teridentifikasi sebagai berikut. Pertama, beralihnya mata pencaharian masyarakat dari pekerjaan di sektor pertanian ke sektor industri, khususnya usaha IKRT. Usaha IKRT telah menciptakan lapangan pekerjaan baru bagi masyarakat di Kecamatan Ciparay. Namun, perkembangan IKRT yang tidak diimbangi dengan kualitas sumber daya manusia yang handal berdampak pada kurang optimalnya usaha IKRT di Kecamatan Ciparay. Kedua, penurunan kualitas lingkungan. Sebagian besar usaha IKRT di Kecamatan Ciparay masih menggunakan metode lama dan sederhana dalam proses produksi dan kurang didukung oleh sanitasi dan pengolahan limbah yang baik sehingga dimungkinkan terjadinya polusi dan pencemaran limbah. Hal ini akan berdampak terhadap penurunan kualitas lingkungan dan kondisi kesehatan para tenaga kerja dan masyarakat yang tinggal di sekitar industri. Ketiga, pertumbuhan ekonomi yang berjalan lambat. Akibat kurang berkembangnya usaha IKRT di Kecamatan Ciparay berdampak pada pertumbuhan ekonomi lokal yang kurang aktif. Dampak dari pertumbuhan ekonomi yang lambat di Kecamatan Ciparay tersebut yaitu semakin banyaknya masyarakat yang masuk dalam golongan miskin dan tingkat pendidikan yang rendah. Hal ini juga akan menyebabkan pembangunan secara keseluruhan di Kecamatan Ciparay akan terhambat sehingga akan tertinggal dengan kecamatan lainnya khususnya yang terdapat di Kabupaten Bandung. Berdasarkan studi sebelumnya, menyebutkan bahwa pada umumnya kegiatan industri rumah tangga dilakukan oleh kaum miskin yang lebih bersifat "supply-pushed activities" dibandingkan "demand-pulled activities". Sebagian besar penduduk yang tinggal di daerah pedesaan melakukan kegiatan 
karena "terpaksa" akibat tidak dapat memperoleh pekerjaan yang lebih baik di tempat lain karena beberapa faktor diantaranya yaitu faktor pendidikan dan/atau faktor pendapatan pada pekerjaan sebelumnya yang lebih rendah. Selain itu, menurut hasil penelitian oleh Tambunan (1994) tentang peranan IKRT di Provinsi Jawa Barat memperlihatkan bahwa peranan IKRT pada sektor industri pengolahan memiliki kontribusi yang lebih besar dibandingkan dengan peranan industri menengah dan besar khususnya dalam hal penyerapan tenaga kerja. Namun, dalam hal kontribusi terhadap PDRB, peranan IKRT memiliki pengaruh yang sangat kecil. Selain itu, hasil penelitian menunjukkan bahwa dampak multiplier IKRT sangat kecil. Hasil penelitian tersebut sejalan dengan kondisi yang terjadi pada usaha IKRT yang terdapat di Kecamatan Ciparay.

\section{Tanggapan}

Menghadapi berbagai permasalahan dan tantangan yang dihadapi terkait perkembangan IKRT di Kecamatan Ciparay, beberapa pihak baik dari pemerintah pusat, pemerintah daerah Provinsi Jawa Barat, Kabupaten Bandung maupun Kecamatan Ciparay telah berusaha melakukan beberapa tindakan tanggapan. Salah satunya melalui kebijakan dan strategi untuk menyelesaikan isu terkait dengan eksternalitas industrialisasi dan pertumbuhan ekonomi lokal yang berjalan melambat. Pada tingkat kecamatan, berdasarkan hasil wawancara dengan pihak dari kantor kecamatan diketahui bahwa telah ada program pelatihan, alih teknologi, dan pemberian modal terhadap usaha IKRT di Kecamatan Ciparay. Namun, program tersebut belum tersebar merata ke seluruh usaha IKRT yang ada di wilayah studi. Hal ini perlu menjadi perhatian khusus dan bahan evaluasi bagi pemerintah daerah di masa mendatang. Pada tingkat kabupaten, pemerintah daerah telah turun tangan dalam mendukung usaha IKRT yang ada di wilayahnya. Hal ini terlihat dari program atau kegiatan yang sudah pernah dilaksanakan dalam upaya mendukung perkembangan usaha IKRT, misalnya pemberian pelatihan tata cara produksi, pemasaran, dan permodalan. Selain itu, pemerintah kabupaten juga pernah melakukan kerjasama dengan Departemen Kesehatan dalam upaya untuk meninjau keamanan bahan baku yang digunakan dalam proses produksi industri, salah satunya pada industri tahu. Adapun dalam upaya mendukung perkembangan industri kecil di Kecamatan Ciparay, pemerintah memiliki berbagai program seperti (1) melakukan pengawasan perkembangan industri pengolahan, (2) melakukan intervensi jika terdapat insiden persaingan ekonomi negatif dalam pengembangan industri pengolahan, dan (3) memberikan pelatihan sebanyak tiga kali dalam setahun. Dari ketiga program tersebut, kemudian dijabarkan menjadi berbagai program yang telah dilaksanakan seperti memberikan pelayanan yang baik dalam pembuatan surat izin dan pajak, peninjauan bahan baku yang akan diolah, memberikan pelatihan produksi, permodalan dan pemasaran produk, memberikan fasilitas simpan pinjam modal, serta pembangunan fisik desa seperti perbaikan jalan lokal.

Berdasarkan kebijakan tingkat provinsi, pengembangan IKRT telah menjadi salah satu prioritas utama bagi pengembangan perekonomian Provinsi Jawa Barat. Upaya yang dilakukan oleh pemerintah daerah Provinsi Jawa Barat dalam pengembangan usaha IKRT adalah dengan membangun sentra-sentra IKRT yang telah ada dan membentuk IKRT yang baru (Disperindag Jabar, 2013). Sedangkan pada tingkat nasional, pemberdayaan UMKM telah diatur dalam Undang-Undang (UU) No. 20 Tahun 2008 tentang UMKM, antara lain mengamanatkan pemerintah pusat maupun daerah dalam: (1) pemberian kemudahan/mendorong perluasan sumber pendanaan/akses kredit; (2) pembangunan prasarana umum, lokasi pasar, pemanfaatan bank data; (3) jaringan informasi bisnis dan fasilitas kepemilikan Hak Kekayaan Intelektual (HAKI); pengembangan kemitraan yang saling menguntungkan antara UMKM dan usaha besar; pembebasan biaya perizinan untuk usaha mikro; dan (4) pemberian keringanan untuk usaha kecil; serta promosi dan 
pengutamaan penggunaan produk UMKM. Dukungan bagi pemberdayaan UMKM juga akan diperkuat dalam UU Perindustrian dan UU Perdagangan yang saat ini masih dalam proses pembahasan, diantaranya: (1) RUU Perdagangan dengan pemberian fasilitasi, insentif, bimbingan insentif, bimbingan teknis, bantuan promosi dan pemasaran; (2) RUU Perindustrian melalui pembangunan IKM ditujukan untuk membangun daya saing dan memperkuat struktur industri nasional dan bentuk faslitasi yang bisa diberikan seperti diklat, bimbingan teknis dan bantuan peralatan, peromosi dan pemasaran, serta kemudahan pembiayaan, pengembangan hunungan kemitraan antar industri terkait.

Berdasarkan beberapa tanggapan yang dinyatakan di atas, terlihat bahwa sudah ada keseriusan pemerintah baik pusat maupun daerah dalam mendukung perkembangan usaha IKRT khususnya di Kecamatan Ciparay. Namun, hal yang perlu disoroti adalah sinkronisasi kebijakan dan strategi yang ada tersebut antar tingkatan pemerintahan. Selain itu, perlu diperhatikan juga terkait dengan pelaksanaan, pemantauan dan evaluasi dari program yang ada.

\section{KESIMPULAN}

Dalam kasus usaha IKRT di Kecamatan Ciparay, pendekatan model DPSIR telah mampu mengidentifikasi beberapa faktor pendorong dan dampaknya terhadap suatu sistem secara menyeluruh. Berdasarkan hasil analisis yang dilakukan di Kecamatan Ciparay terhadap perkembangan ekonomi lokal berupa usaha IKRT, model DPSIR secara umum telah menggambarkan beberapa hal terkait dengan kurang optimalnya usaha tersebut. Industrialisasi, perkembangan ekonomi dan dinamika sosial penduduk, sumber daya (tenaga kerja, pendanaan, bahan baku) yang ada, dukungan pemerintah dan swasta, serta kurangnya dukungan infrastruktur yang memadai merupakan sebagian besar hal pendorong yang mengakibatkan tekanan terhadap perkembangan perekomian di daerah tersebut. Perhatian yang cukup dari pemerintah daerah dan pembuat kebijakan menjadi sorotan penting dalam mendukung usaha IKRT di Kecamatan Ciparay. Kecamatan Ciparay memiliki potensi besar dalam hal sumber penghasil pangan untuk menyokong Kabupaten Bandung dan sekitarnya, namun kebijakan yang ada lebih menekankan daerah tersebut untuk dikembangkan sebagai daerah sentra pertanian, sehingga keberadaan usaha IKRT berjalan kurang optimal. Oleh karena itu, kebijakan yang ada perlu ditinjau kembali sehingga perkembangan ekonomi lokal, khususnya industri pengolahan hasil pertanian bagi usaha IKRT dapat berlanjut secara mandiri dan umumnya memberikan kontribusi positif bagi perekonomian lokal di Kecamatan Ciparay.

Ucapan Terimakasih

Kami ingin mengucapkan terimakasih dan apresiasi kepada para peserta mata kuliah Studio Proses Perencanaan kelas C angkatan 2012, Program Studi Perencanaan Wilayah dan Kota, Sekolah Arsitektur, Perencanaan dan Pengembangan Kebijakan, Institut Teknologi Bandung, serta beberapa pihak yang telah membantu dalam pelaksanaan kegiatan studio di Kecamatan Ciparay, Kabupaten Bandung.

\section{DAFTAR PUSTAKA}

Kabupaten Bandung Dalam Angka 2014. Badan Pusat Statistik Kabupaten Bandung, 2014. (http://bandungkab.bps.go.id/publikasi/kabupaten-bandung-dalam-angka-2014). Diakses pada 20 Januari 2015.

Kecamatan Ciparay Dalam Angka 2014. Badan Pusat Statistik Kabupaten Bandung. (http://bandungkab.bps.go.id/publikasi/kecamatan-ciparay-dalam-angka-2014-0). Diakses pada 20 Januari 2015. 
Anderson, D. 1982. "Small Industry in Developing Countries: A Discussion of the Issues." World Development, Vol. 10, No. 11, pp. 913-948.

Disperindag Jawa Barat. 2013. Data Statistik Industri Kecil dan Menengah Provinsi Jawa Barat. Dinas Perindustrian dan Perdagangan Provinsi Jawa Barat. (http://disperindag.jabar.go.id). Diakses pada 20 Januari 2015.

Kementerian Koperasi dan UMKM 2013. Perkembangan Data Usaha Mikro, Kecil, Menengah (UMKM) dan Usaha Besar (UB) Tahun 2007-2012. (http://www.depkop.go.id ). Diakses pada 20 Januari 2015.

Nu'man, A. H. 2005. "Kebijakan Pengembangan Industri Kecil dan Menengah Sebagai Upaya Untuk Menghadapi Era Perdagangan Bebas (Suatu Model Konseptual dalam Pengembangan IKM)." Mimbar Jurnal Sosial dan Pembangunan, Vol. XXI, No. 3, UNISBA.

OECD. 1993. OECD Core Set of Indicators for Environmental Performance Reviews. OECD Environment monographs No. 83. OECD, Paris. 39pp.

Pinter, L., Cressman, D.R., and Zahedi, K. 1999. Capacity Building for Integrated Environmental assessment and Reporting: Trainning Manual. UNEP, IISD and Ecologistics International Ltd.

Rahmayanti, I. 2007. Kajian Pengembangan Industri Kecil dan Rumah Tangga Berbasis Komoditas Unggulan di Kabupaten Subang. Tugas Akhir. Bandung: Institut Teknologi Bandung.

Smeets, E. and Weterings, R. 1999. Environmental Indicators: Typology and Overview. Technical Report No. 25. European Environment Agency, Copenhagen. 19pp.

Tambunan, T. 1994. "Mengukur Besarnya Peranan Industri Kecil Dan Rumah Tangga Di Dalam Perekonomian Regional: Beberapa Indikator.” Agro-Ekonomika, No.1. Yayasan Agro-Ekonomika, Yogyakarta. 